\title{
セルオートマトン法を用いた海浜変形予測モデル
}

\section{A Model for Predicting Beach Changes using Cellular Automaton Method}

\author{
遠藤将利 $^{1}$ ・ 小林昭男 ${ }^{2} \cdot$ 宇多高明 $^{3}$ ・ 芹沢真澄 ${ }^{4} \cdot$ 野志保仁 $^{5}$ \\ Masatoshi ENDO, Akio KOBAYASHI, Takaaki UDA, Masumi SERIZAWA and Yasuhito NOSHI
}

\begin{abstract}
A model for predicting beach changes using a cellular automaton method was developed, in which sand transport under the ongoing and outgoing waves is separately calculated in accordance with the fundamental concept of the BG model proposed by Serizawa et al. The model was applied to the beach changes on the gently sloping revetment of the Katsuyama coast, and also applied to a model case, in which sand is trapped in the holes excavated on a reef flat by coral mining.
\end{abstract}

\section{1.はじめに}

芹沢ら（2006）は，実用的海浜変形モデルとしてBG モデル（Bagnold概念に基づく海浜変形モデル）を提案 し, 種々の条件での海浜変形予測を行うことにより, BG モデルの汎用性がかなり高いことを明らかにした。BG モデルでは，波作用下における漂砂を寄せ波時の岸向き 流れによる成分と, 引き波時の沖向き流れによる成分か らなると考え, 両者の和からネットの漂砂を求め, これ を基礎式として用いている. ところで, 現地海岸では傾 斜護岸のように平衡勾配よりも急な斜面に砂が這い上が り，階段上に堆積する現象がしばしば観察される。また， 急な前浜にうち上げられた細砂が後浜に留まる現象も見 られる．芹沢らのBGモデルでは，モデルの性質上この ような平衡勾配, もしくはそれより勾配が急な斜面上を 砂が岸向きに移動するという現象は再現できなかった. これは, 式の誘導の過程で寄せ波と引き波の和として求 めたネットの漂砂量式を計算の基礎式として用いている ことによる. 本研究では, BGモデルの基本に立ち返り, 寄せ波時と引き波時の砂移動を別々に扱う方式を採用す るとともに, 新たにセルオートマトン法を導入し, 上記 現象を再現可能な海浜変形予測モデルを開発した.

\section{2. 計算モデル}

セルオートマトン法とは, 地形を格子状に切り, 各 cellに対して波の作用により砂が移動する際のルールを

\begin{tabular}{|c|c|c|}
\hline 1 学生会員 & 修 (工) & 日本大学大学院理工学研究科 \\
\hline 2 正会員 & 工博 & 日本大学教授理工学部海洋建築工学科 \\
\hline 3 正会員 & 工博 & $\begin{array}{l}\text { (財) 土木研究センター常務理事なぎさ } \\
\text { 総合研究室長兼日本大学客員教授理工学 } \\
\text { 部海洋建築工学科 }\end{array}$ \\
\hline 4 正会員 & & 海岸研究室 (有) \\
\hline 正会員 & 博 (工) & (有) アイコムネット環境コンサルテイング部 \\
\hline
\end{tabular}

設定し，それを全ての cellに適用することで各 cellの砂の 移動量・移動距離を定める離散型の計算手法であり, 従 来, 砂丘におけるバルハンの発達の計算（西森・大内, 1993）などに用いられるとともに，流体・粉体の流れの 計算, 交通流の計算, 生命現象のモデル化など多岐な分 野で利用されてきている（例えば，森下，2003）。図-1 にモデルの模式図を示す，沖から岸向きにx軸を定め, 鉛直方向に地盤高 $Z$ を取る. $Z$ の基準は静水面に置く. 寄せ波時には，図-1（a）のようにある cellに注目し，ま ず岸向きに運ばれる砂の量 $V^{+}$計算し, それを波の進行 方向に1つ岸側の cellに移動させる. 引き波時にはこれと 逆にV-を計算し，1つ沖側の cellに移動させる.また，固 定床を設けた計算では, ある cellにおいて計算された砂 の移動量よりも少ない量しか固定床上に砂がない場合, その全量を移動させる。

図-2 は計算フローを示す。計算に必要な初期条件を入 力した後, 寄せ波による砂移動を計算する. 各 cellでそ れぞれの砂の移動量を求めた後, 砂の移動は全 cellで一
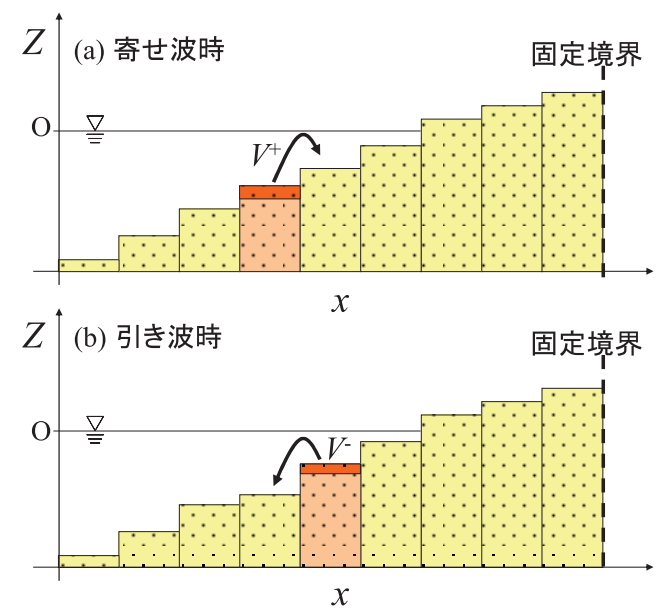

図-1 モデルの模式図 
斉に行う。その後, 引き波時の計算を同様に行い, 寄せ 波・引き波の作用 1 回を 1 step として, これを全体でN step繰り返す.

本研究では, 地形変化計算は時間発展方式で行い, 各 step ステップで寄せ波と引き波を交互に 1 回ずつ作用さ せた，砂の移動量については，Bagnold（1963）による一 方向流れに対する掃流砂式を海底勾配に関して線型近似 したBowen（1980）の漂砂式を念頭に置き，寄せ波時の 移動量 $V^{+}$と引き波時の移動量 $V$ に分けて与えた（式（1）, (2)).

$$
\begin{aligned}
& V^{+}=V_{0}\left(1-\frac{\tan \beta_{i}}{\tan \phi}\right) \\
& V^{-}=b \cdot V_{0}\left(1+\frac{\tan \beta_{i}}{\tan \phi}\right)
\end{aligned}
$$

ここに, $\tan \beta_{\mathrm{i}}$ : 波の進行方向の局所勾配（寄せ 波: $\frac{\partial Z}{\partial x}$, 引き波: $\left.-\frac{\partial Z}{\partial x}\right),:$ 平坦面上 $\left(\tan \beta_{\mathrm{i}}=0\right)$ での砂 の移動量, $\mathrm{b}$ : 平坦面上での寄せ波時に対する引き波時 の砂移動量の比 $(0<b<1), \tan \phi:$ 安息勾配 (1/2) である. 砂の移動方向は流れの方向と同一とする。式 (1), (2) では，安息勾配に対する局所勾配の比が漂砂量を定める 上で決定的な役割を果たす．傾斜がある場合，重力作用 を考慮すると水平床での移動量に比べて上り勾配では砂 の移動量は小さくなり（式（1））, 下り勾配では砂の移 動量は大きくなる（式（2））.

寄せ波と引き波による漂砂量が等しいとき，すなわち ネットの漂砂量が 0 となったときに平衡勾配となり, 地 形は安定に至ることから，

$$
V=V^{+}+\left(-V^{-}\right)=0
$$

を得る。式（3）に式（1），(2）を代入し, 平衡状態 における $\tan \beta_{\mathrm{i}}=\tan \beta_{\mathrm{C}}$ の関係を利用して $\tan \beta_{\mathrm{C}}$ について解く と式 (4) が得られる.

$$
\tan \beta_{C}=\left(\frac{1-b}{1+b}\right) \cdot \tan \phi
$$

$b$ を寄せ波と引き波のエネルギー損失量の比率 $c$ とすれ ば，式（4）はInman and Bagnold（1963）によって誘導 された平衡勾配の式に等しい. Inman and Bagnoldが述べ たように，bは波作用の非対称性の度合いとして $0 \sim 1$ の 值をとる．寄せ波と引き波の作用が等しい場合 $(b=1)$, 平衡勾配は 0 となる。 また寄せ波と引き波の作用の非対 称性が強いほど（bが小さいほど）平衡勾配は急勾配と

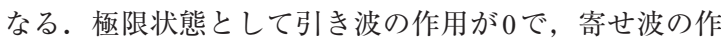
用のみ $(c=0)$ の場合, 平衡勾配は安息勾配 $\tan \phi$ となる. また, 式（4）をbについて解くと式（5）となる.

$$
b=\frac{\tan \phi-\tan \beta_{C}}{\tan \phi+\tan \beta_{C}}
$$

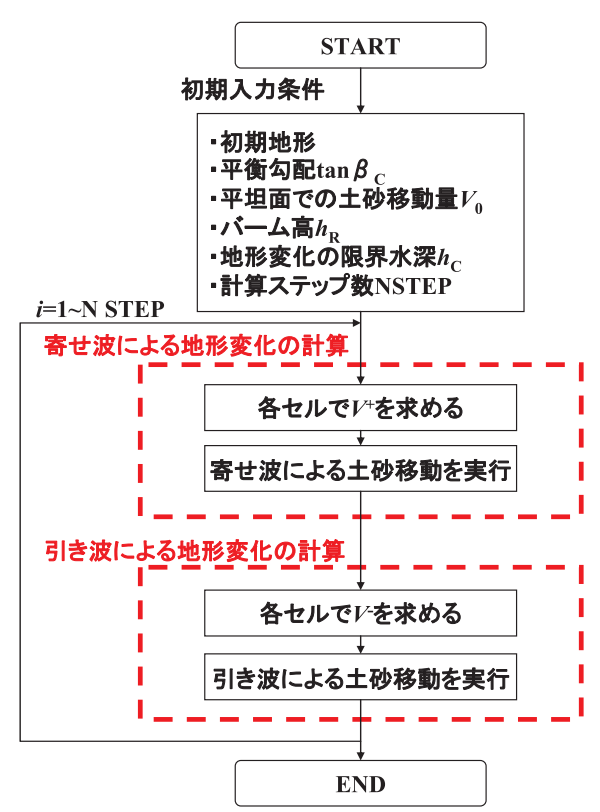

図-2 計算フロー

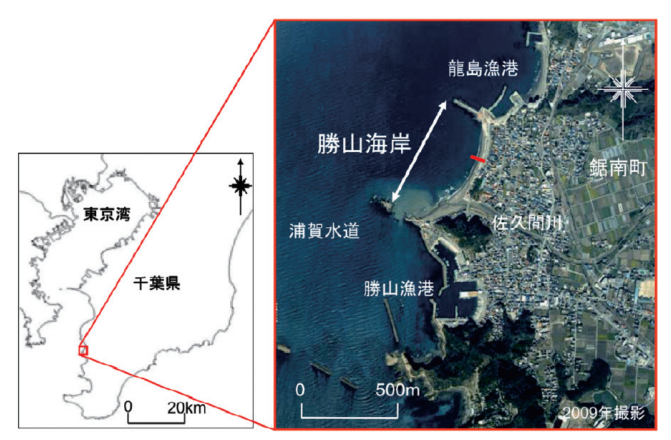

図-3 勝山海岸の位置

数值計算では, 従来の BG モデルと同様に平衡勾配を 入力することとし，式（5）よりbを算出して計算に用い る. 式 (1), (2) の局所勾配 $\tan \beta_{i}$ の計算は, 着目 cellの 地盤高 $Z_{1}$ と下手側（寄せ波時は岸側，引き波時は沖側） の隣接 cellの標高 $Z_{2}$ の差分を cell間隔 $\Delta \mathrm{x}$ で割ることによ り, $\tan \beta_{i}=\left(Z_{2}-Z_{1}\right) / \Delta \mathrm{x}$ より算出する。また, 安息勾配以 上の急斜面では砂が上れない $($ 移動量 $=0)$. さらに, バ 一ム高 $h_{\mathrm{R}}$ より標高が高い場合，もしくは波による地形変 化の限界水深 $\left(h_{C}\right)$ 以深では砂の移動量を 0 とする. 以 上のルールをモデル化して計算を行った。

\section{3. 勝山海岸で実測された傾斜堤上への砂の堆積 現象}

勝山海岸は, 図-3に示すように房総半島南部にあり浦 賀水道に面している. 海岸の北側を龍島漁港, 南側を勝 山漁港により挟まれた長さ約 $600 \mathrm{~m}$ のポケットビーチで 


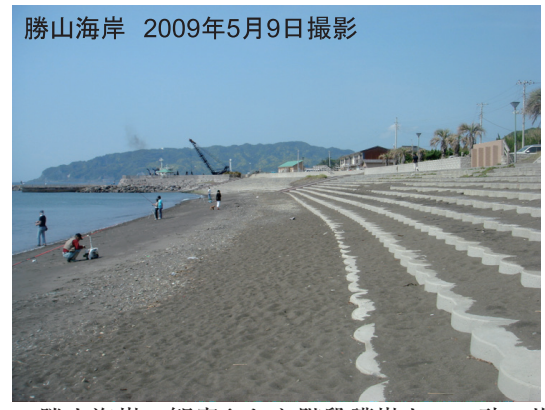

図-4 勝山海岸で観察された階段護岸上への砂の堆積 （2009年5月9日）

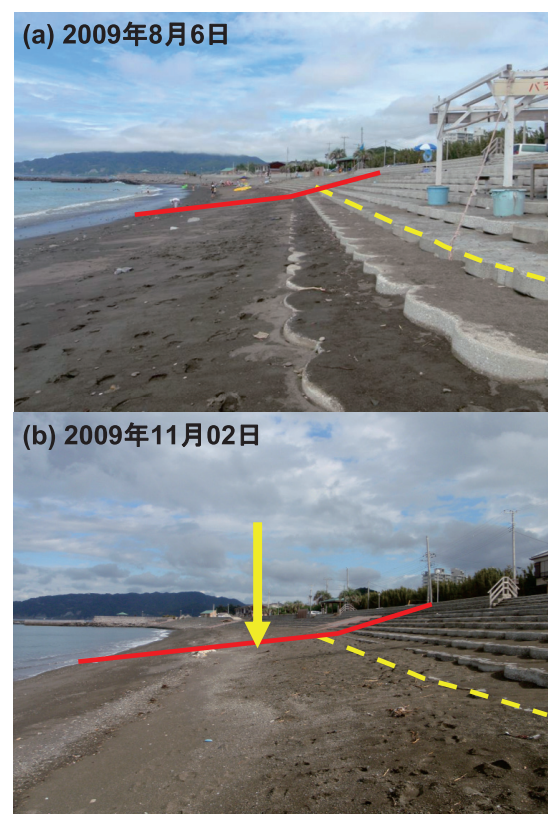

図-5 砂の堆積前後の比較（2009年8月6日vs. 11月 2日）

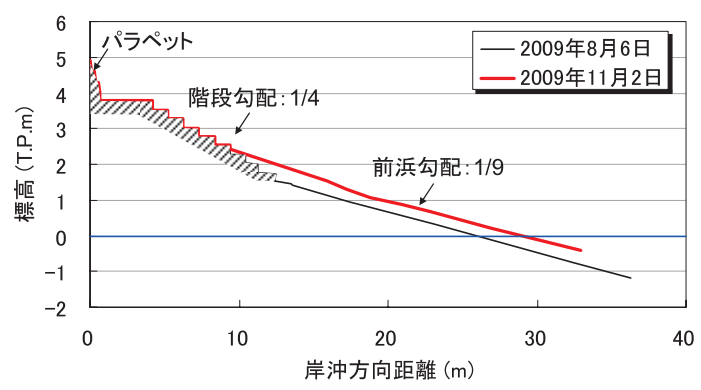

図-6 階段護岸上への砂の堆積

(2009年8月6日 vs. 11月 2日)

ある．勝山海岸には階段護岸が設置されているが，2009 年 5 月 9 日踏査時, 図-4のように階段護岸上への堆砂が観 察された。図-5には大貫ら（2010）が行った定点観測写 真を示す. 図-5 (a), (b) の破線は同じ階段位置を示す.

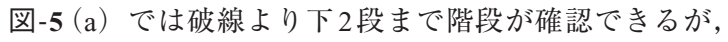
図-5（b）では堆積した砂により階段護岸が埋り，見えな
表-1 計算条件

\begin{tabular}{l|c|c|c|c}
\hline 計算ケース & 1 & 2 & 3 & 4 \\
\hline 初期海浜勾配 & $1 / 9$ & $1 / 9$ & & \\
\hline 平衡勾配 $\beta$ & $1 / 9$ & $1 / 9$ & $1 / 10$ & $1 / 10$ \\
\hline 寄せ波に対する引き時の移動量の比 $b$ & 0.63 & 0.63 & 0.67 & 0.67 \\
\hline 平坦面での砂の移動量 $V_{0}$ & 0.05 & 0.05 & 0.1 & 0.1 \\
\hline 地形変化の限界水深 $h \mathrm{c}(\mathrm{m})$ & -8 & -8 & -3 & -3 \\
\hline バーム高 $h \mathrm{R}(\mathrm{m})$ & 3 & 3 & 1 & 1 \\
\hline 計算メッシュ $\Delta \mathrm{Y}(\mathrm{m})$ & 0.25 & 0.25 & 1 & 1 \\
\hline 計算ステップ数 & $15 \times 10^{3}$ & $15 \times 10^{3}$ & $30 \times 10^{3}$ & $30 \times 10^{3}$ \\
\hline
\end{tabular}
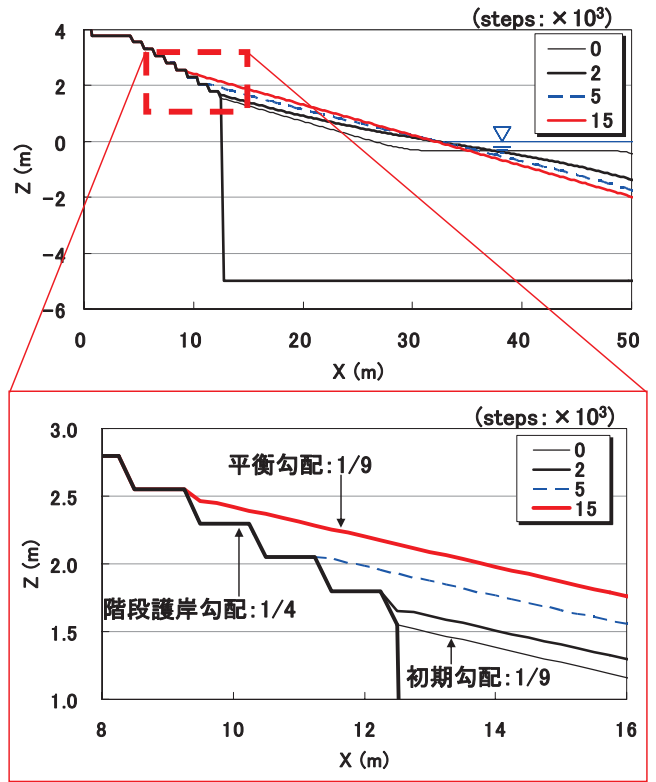

図-7 階段護岸上への砂の堆積の計算結果（ケース 1)

くなっている．この結果，前浜が見かけ上広がっている. 図-6には図-3，5に赤線で示した測線での地形測量の結果 を示す。 2009 年 8 月 6 日には $1 / 4$ 勾配の階段護岸の前面に 前浜勾配1/9の砂浜があったが，2009年11月 2 日の測量 では前浜勾配はほほ一定值を保ったまま砂が堆積して全 体に海浜地盤高が上昇し, 階段護岸の下 3 段を埋めて砂 が堆積した。

\section{4. セルオートマトン法の適用}

3.で述べた階段護岸上での砂の堆積現象を対象として 再現計算（ケース1）を行った.ここで, 図-5 (b) の海 浜ほぼ中央に示す矢印位置に波の遡上痕跡が確認できる ことから判断すると, 静穏時には波は護岸基部まで作用 していない.しかし, 高波浪時には岸沖モードの漂砂が 卓越することによって, 護岸上に砂が堆積したものと考 えられる。このことから, 図-6に示した地形変化は岸沖 漂砂のみに起因したと仮定して計算を行った。表-1には 


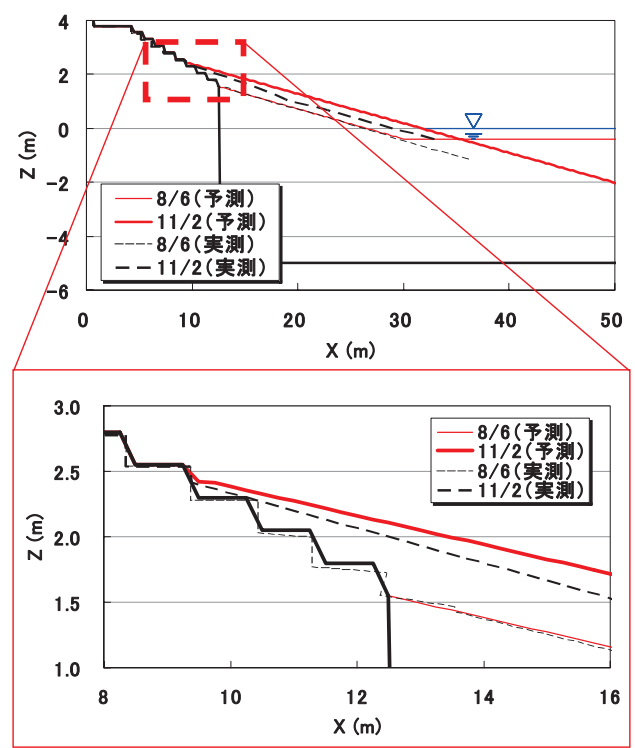

図-8 実測と再現計算の比較（ケース 1)

計算条件を示す。この計算では, 実測縦断形を初期形状 として与えて計算を行った。初期縦断形は平衡勾配が $1 / 9$ の前浜とし，その後の堆積状況を再現するために沖側に 実測から得た土砂量分を養浜したという想定で計算を行 った．階段護岸は固定床として扱った，図-7にはケース 1 の計算結果を示す. 2,000stepでは沖で養浜された砂が 岸向きに移動し，階段護岸の蹴り上げの壁面により岸向 き移動が阻止される。しかし5,000stepでは，下段に砂が 十分堆積したためその上の段に砂が堆積している．最終 的に，沖の地形も平衡勾配に近づき岸側へと寄せられた 砂は前浜勾配 $1 / 9$ を保ったまま階段の上段に堆積した。 このように階段の下段〜上段へと続く砂で覆われた斜面 が形成され，砂浜は平衡勾配を持つことによって安定と なる．図-8は測量結果と計算結果を比較したものである (破線：実測, 実線：計算)。最終安定形状の地形を比較 すると良い一致を示すことが分かる。このように砂が階 段護岸上に堆積する現象の再現が可能になった。

実現象では，寄せ波時において平衡勾配より急斜面で あっても，安息勾配を越えるような極端な急斜面でない 限り，砂は岸向きに移動することができる，さらに移動 した先が平坦面であった場合，引き波による砂の移動量 は減り，砂はそこに留まる。すなわち，寄せ波・引き波 の砂の移動距離が重要な要素になると考えられる.

このような寄せ波・引き波による砂移動距離の差を再 現するため，寄せ波の計算を $n$ 回，引き波の計算を $m$ 回 行う手法を考えた。これは，寄せ波時には $n$ メッシュ分 岸側に移動し，引き波時には $m$ メッシュ分沖側へ移動す ることと同義である。この条件の下で，寄せ波と引き波

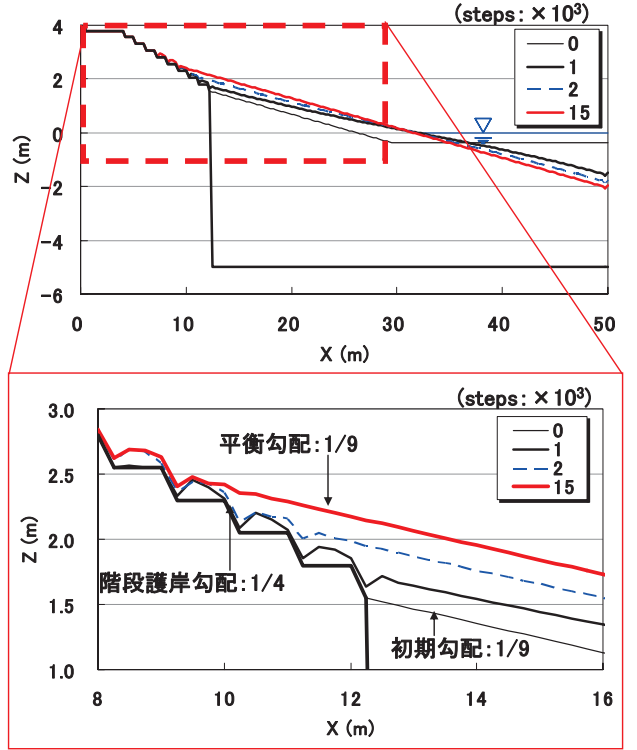

図-9階段護岸上への砂の堆積（ケース2）

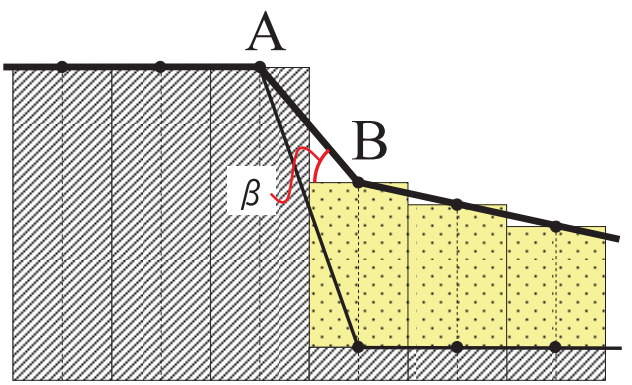

図-10 局所勾配の模式図

時における土砂移動量が等しくなるためには，寄せ波時 に対して引き波時の砂移動量を $n / m$ 倍する必要があり, その場合, 式（3）に代わって式（6）が満足されねばな らない.

$$
V=n V^{+}+\left(-m V^{-}\right)=0
$$

ケース 2 では $n=3, m=1$ として計算を行った。図-9にケ ース 2 の計算結果を示す。初期海浜勾配は $1 / 9$ と，砂の平 衡勾配 $1 / 9$ と等しいが，X=30mより沖合を平坦面で与え ているため岸向き漂砂が生じ，階段護岸部分への堆積が 起こる。図-10の模式図に示すように，階段護岸のある ステップに注目すると，あるステップ間の階段勾配が $1 / 2$ （安息勾配）より急な場合，原理上砂は上のステップに 這い上がれず，図に示すA点と砂面上のB点との勾配が $1 / 2$ より緩くなって始めて上段のステップに砂が上ること ができる。このようにして階段上への堆積が始まると， 下段〜上段へと砂で覆われた斜面が形成され，各段上の 


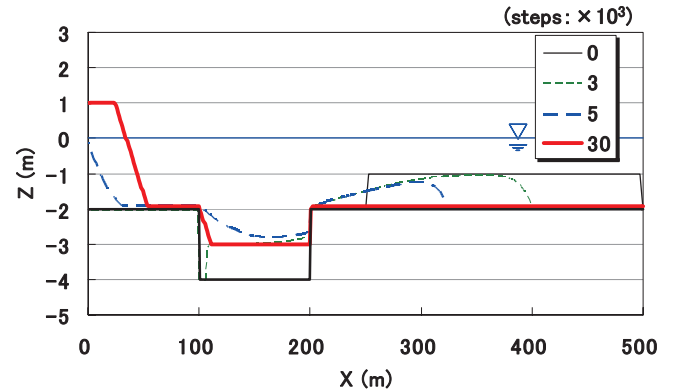

図-11 リーフ掘削による岸向き漂砂のトラップ（ケース3)

砂浜は平衡勾配に至って安定する.

勝山海水浴場で観察された階段護岸上の砂の堆積状況 では，11月2日には図-6のように階段ののり先が砂で埋 まっていたが, その堆積過程に抢いては図-4に示したよ うに階段の隅角部のみに砂が堆積していた。ケース 2 の 計算結果はこれをよく再現できている。このように寄せ 波と引き波の作用を別々に取り扱うことで, 従来のBG モデルでは再現が難しかった平衡勾配より急勾配の斜面 上を砂が岸向きに上る現象が再現できる.

\section{Coral miningで形成された穴による漂砂の トラップ}

ケース 3，4では, リーフ上で coral miningが行われて 掘削穴が形成され，それによってリーフエッジから海浜 への漂砂が絶たれるという条件を想定し, 岸向き漂砂の トラップ現象（Seino et al., 2006）を対象とした計算を 行った.リーフエッジから海浜への砂供給を模すために, $\mathrm{X}=250 \sim 500 \mathrm{~m}$ の $250 \mathrm{~m}$ 区間で厚さ $1 \mathrm{~m}$ の矩形状養浜を考え た．岸向き漂砂をトラップする掘削穴は，X=100〜200 $\mathrm{m}$ 間にリーフの平坦面から $2 \mathrm{~m}$ の深さまでの矩形状の穴と した。リーフ面扮よび掘削穴は固定床として扱った。計 算条件は表-1に示す.

ケース 3 の計算結果を図-11に示す，沖に置かれた砂は 波の作用で沖側を中心として削り取られ，その砂が徐々 に岸向きに移動し掘削穴に落ち込む. 穴に落ち込んだ砂 は当初穴の陸側側面の勾配が急なため穴から這い上がる ことはできず，岸向き移動は阻止される．しかし掘削穴 内に打ける波による地形変化の限界水深（-3m）以深が砂 で満たされた後は，掘削穴の岸側側面に平衡勾配を有す る斜面が形成される。これにより沖から運ばれた砂が掘 削穴から出ることが可能となり, $30 \times 10^{4}$ step では縦断形 は安定状態に達する。同様に, 掘削穴が複数あるケース 4 の計算結果を図-11に示すが，この場合も，ケース 3 と同 様, 掘削穴の埋没と岸向き漂砂が起こり, 掘削穴(1)(2)の 順に砂が堆積し，それぞれの掘削穴の岸側側面に平衡勾 配を有する斜面が形成され, 最終的に海浜が形成される.

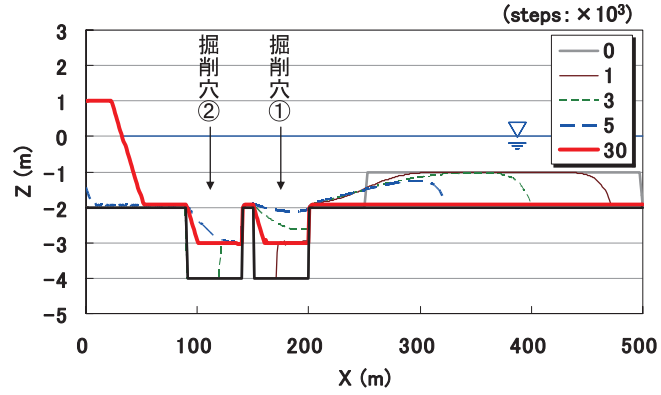

図-12 リーフ掘削（複数）による岸向き漂砂のトラップ (ケース 4)

\section{6. まとめ}

寄せ波・引き波時の漂砂バランスにより平衡勾配が形 成されることを原理として，セルオートマトン法を導入 した海浜変形予測モデルを開発した。 これによれば階段 護岸上に砂が堆積する現象や, リーフ掘削による岸向き 漂砂のトラップ現象などの予測が可能となった。本研究 は，セルオートマトン法による海浜変形モデルの開発の 第一歩であって, 現段階では, 式 (1), (2) の平坦面上 での砂移動量 $V_{0}$ を直接与えるという最も単純な方式をと っており，波浪外力を直接用いていない。 $V_{0}$ は本来，砕 波点での波浪外力と結び付けられるべきものであり，ま た，時間スケールの概念が直接式に含まれておらず漂砂 量係数も用いていない.さらに, 時間間隔とセルの大き さ， $n, m$ の值の設定法なども十分明確でない. 今後実務 に使用可能なモデルとするには, これらの課題の解決が 必要である.

\section{参 考 文 献}

大貫 崇 - 小林昭男 - 宇多高明 - 野志保仁 - 遠藤将利 (2010)：人為的改変に伴う自然海浜の狭小化-千葉県勝山 海岸の例-, 日本沿岸域学会研究討論会 2010 講演概要集, No.23 (PDF), セッション09-01.

芹沢真澄 - 宇多高明 - 三波俊朗 - 古池 鋼 (2006)：Bagnold 概念に基づく海浜変形予測モデル，土木学会論文集 B, Vol.62, No.4, pp.330-347.

西森 拓・大内則幸（1993）: 飛砂による地形の動力学, 物性 研究, $61,1, p .32$.

森下 信 (2003) : セルオートマトン-複雑系の具象化, 養賢 堂, pp.166.

Bagnold, R. A. (1963): Mechanics of Marine Sedimentation, in The Sea, M. N. Hill(editor), Vol. 3, pp. 507-528, New York, Wiley.

Bowen, A. J. (1980): Simple models for nearshore sedimentation; beach profiles and longshore bars, in The Coastline of Canada, The Geological Survey of Canada, S.B. McCanann, (editor), Paper 80-10, pp.1-11.

Inman, D. L. and Bagnold, R. A. (1963): Littoral processes, in The Sea, M.N. Hill, (editor), Vol. 3, pp. 529-533, New York, Wiley.

Seino, S., T. Uda, S. Onaka, M. Serizawa and T. San-nami (2006): Large-scale excavation and land reclamation on reef flat and coral mining on Turtle Island in Bali, Indonesia, Proc. 10th International Coral Reef Symposium, pp. 876-881. 